\title{
The New Law of Piercing the Corporate Veil in the UK
}

Schall, Alexander

Published in:

European Company and Financial Law Review

DOI:

10.1515/ecfr-2016-5005

Publication date:

2016

\section{Document Version}

Publisher's PDF, also known as Version of record

Link to publication

Citation for pulished version (APA):

Schall, A. (2016). The New Law of Piercing the Corporate Veil in the UK. European Company and Financial Law Review, 13(4), 549-574. https://doi.org/10.1515/ecfr-2016-5005

\section{General rights}

Copyright and moral rights for the publications made accessible in the public portal are retained by the authors and/or other copyright owners and it is a condition of accessing publications that users recognise and abide by the legal requirements associated with these rights.

- Users may download and print one copy of any publication from the public portal for the purpose of private study or research.

- You may not further distribute the material or use it for any profit-making activity or commercial gain

- You may freely distribute the URL identifying the publication in the public portal ?

If you believe that this document breaches copyright please contact us providing details, and we will remove access to the work immediately and investigate your claim. 


\title{
The New Law of Piercing the Corporate Veil in the UK
}

\author{
by \\ AleXANDer SChalL *
}

Table of Contents

ECFR 2016, 549-574

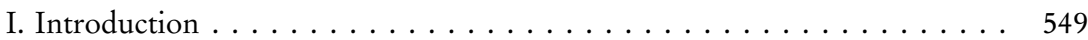

II. Piercing the Corporate Veil after Prest: The will of the Justices . . . . . . . . . 551

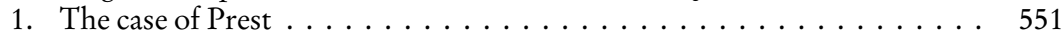

2. The judgement by Lord Sumption . . . . . . . . . . . . . . . 552

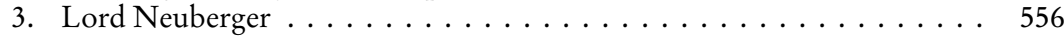

4. Lady Hale (with whom Lord Wilson agreed) . . . . . . . . . . . 557

4. Lord Mance . . . . . . . . . . . . . . . . . . . . . . . . . . . . . 559

5. Lord Clarke of Stone-cum-Ebony . . . . . . . . . . . . . . . . . . . . 560

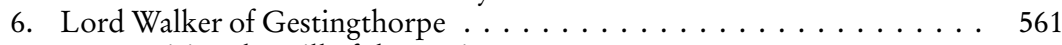

7. Summarising the will of the Justices $\ldots \ldots \ldots \ldots \ldots \ldots \ldots \ldots 61$

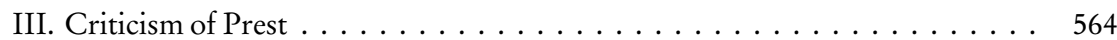

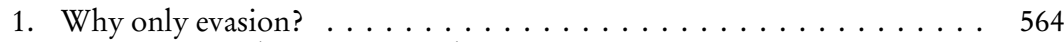

2. Are Trustor and Gencor in truth evasion cases? . . . . . . . . . . . 566

3. Are even Yukong Line and Creasey evasion cases? . . . . . . . . . . . 567

4. Conflict with VTB Capital? . . . . . . . . . . . . . . . . . . . . 568

5. Why evasion at all? . . . . . . . . . . . . . . . . . . . 570

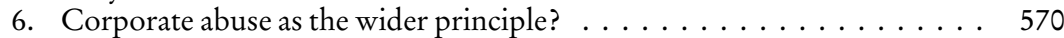

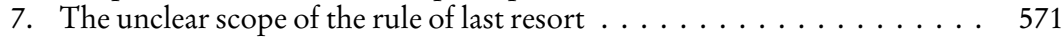

IV. Conclusion . . . . . . . . . . . . . . . . . . . . . . . . . . . . . 573

\section{Introduction}

In a seminal judgement in 2013, Prest $v$ Petrodel, ${ }^{1}$ the English Supreme Court clarified the law of piercing the corporate veil. This had become necessary

* Professor Alexander Schall holds the chair for German, European and International Private, Corporate and Comparative Law at the Law School, Leuphana University Lüneburg.

1 The case is noted by, P Breakey, 'Is Piercing the Veil Contrary to High Authority: A Footnote to the Never Ending Story,' (2013) Comp Law 34(11) 352; E Roxburgh, 'Prest v Petrodel Resources Ltd: Cold Comfort for Mrs Prest in Scotland,' (2013) SLT 32, 223; JHY Chan, 'Should 'Reverse Piercing' of the Corporate Veil be Introduced in English Law,' (2014) Comp Law 35(6) 163; P Bailey, '2013: That Was The Year That Was in 
because, in a growing number of cases, attempts were made to circumvent the separate personality and limited liability of companies. ${ }^{2}$ However, it is well known that English company lawyers were never really fond of piercing the corporate veil. The Supreme Court even went so far as to call the existence of the doctrine into question altogether in VTB Capital. ${ }^{3}$

Soon after VTB Capital, however, Prest apparently confirmed the existence of the doctrine. ${ }^{4}$ It also made an effort to deliver the long missing rationale for piercing the veil by spelling out the "evasion principle" as opposed to the "concealment principle". However, this rationale is extremely narrow and leaves only two classical cases (Jones $v$ Lipman $^{5}$ and Gilford Motors $v$ Horne $^{6}$ ) as good law. Moreover, Prest curtailed the scope of piercing the veil even further. By introducing a "rule of last resort", it turned it into an exceptional remedy that is hardly ever supposed to apply in practice. Arguably, un,der that rule, it would not even have applied in those two very cases that are supposed to carry the principle. Moreover, the justices of the Supreme Court take very different views on the doctrine of piercing the veil as a remedy. In a subsequent judgement in another Gramsci case, ${ }^{7}$ the Court of Appeal went so far as to deny any clear rationale and therefore held that:

"Absent a principle, further development of the law will be difficult for the courts because development of common law and equity is incremental and often by analogical reasoning".

This raises the question where the law on piercing the veil stands today. Therefore, we will interpret the will of the Justices as the oracles of the law (sub II). After that, we will subject it to critical analysis (sub III). Then, we will conclude (sub VI).

Company Law,' (2014) Co. L.N. 347, 1; C Hare, 'Family Division, 0; Chancery Division, 1: piercing the corporate veil in the Supreme Court (again),' (2013) Cambr. L.J. 72(3), 511; R Matthews, 'Clarification of the doctrine of piercing the corporate veil,' (2013) J.I. B.L.R. 28(12), 516; N Grier, 'Piercing the Corporate Veil: Prest v Petrodel Resources Ltd,' (2014) Edinburgh L. R. Vol. 18(2), 275; P Lee, 'The Enigma of Veil-Piercing,' (2015) Int'l Comp. and Comm. L.R. Vol. 26(1), 28.

2 See in particular Burton $\mathrm{J}$ in one of the Gramsci cases, Antonio Gramsci Shipping Corporation v Stepanovs [2011] EWHC 333 (Comm); disapproved by Lord Neuberger in VTB Capital Plc v Nutritek International Corp and others [2013] UKSC 5, at paras. 133 et seq., 147.

3 VTB Capital Plc v Nutritek International Corp and others [2013] UKSC 5.

4 Cf. Prest, para 27 (per Lord Sumption): "In my view, the principle that the court may be justified in piercing the corporate veil if a company's separate legal personality is being abused for the purpose of some relevant wrongdoing is well established in the authorities".

5 Jones $v$ Lipman [1962] 1 WLR 832.

6 Gilford Motor Co Ltd v Horne [1933] Ch 935.

7 Gramsci Shipping Corporation v Lembergs [2013] EWCA Civ 730. 
II. Piercing the Corporate Veil after Prest: The will of the Justices

Prior to Prest, the leading authority in the field of piercing the corporate veil was Adams $v$ Cape Industries ${ }^{8}$ where the Court of Appeal considered - and eventually rejected - three arguments to get around the Salomon principle and pierce the corporate veil of the American subsidiary that had caused harm by producing asbestos. Those headings were:

- Agency

- Single economic unit

- Piercing of the corporate veil under the "fraud exception"

They entered textbooks and practice. ${ }^{9}$ The doctrine of piercing the veil now stated by Prest is only concerned with the third heading, restating the previous "fraud exception" 10 by offering a new, more refined approach to these cases in establishing the "evasion principle", thereby confirming some (Jones $v$ Lipman; Gilford $v$ Horne) but rejecting others (Trustor; Gencor ${ }^{11}$ ). Agency and single economic unit are not dealt with by Prest, and so are not in this article.

\section{The case of Prest}

Prest $\mathrm{v}$ Petrodel rested primarily on section 23 Matrimonial Causes Act 1973. The wife, Mrs Prest, divorced her husband, Mr Prest, who owned several companies. One of these companies, Petrodel, also held the matrimonial home. The wife claimed to be allocated the house under section 23 Matrimonial Causes Act 1973. She based her claim on three arguments:

- Petrodel's veil should be pierced for fraud as the company was a mere façade aimed at disguising the true fact that the husband was the sole owner of the house.

- Section 24(1)(a) Matrimonial Causes Act 1973 should be read as to allow the property of the husband's company being treated as the property of the spouse.

8 Adams v Cape Industries Plc [1990] Ch 433.

9 Cf. eg Re Polly Peck International plc. Barlow \& Ors v Polly Peck International Finance Ltd $\mathcal{E}$ Anor $\left(N^{\circ} 4\right)$ [1996] B.C.C. 486.

10 See in particular Trustor $v$ Smallbone [2001] 1 W.L.R. 1177; Ben Hashem v Al Shayif [2009] 1 FLR 115 (Munby J).

11 Gencor ACP Ltd and others v Glenn Bryan Dalby and others [2000] 2 B.C.L.C. 734. 
- The company was a mere trustee of Mr Prest, and therefore the house was essentially his personal property.

The Supreme Court rejected the appeal on issues 1 and 2 above, but allowed it unanimously on issue 3 . The rejection of the appeal on the point of piercing the corporate veil was accompanied by a fundamental (re)statement of the law in this field. Lord Sumption gave the leading speech. All members of the Supreme Court subsequently gave opinions on the issue. All agreed in principle, but dissented in details that are relevant for interpreting the new law.

\section{The judgement by Lord Sumption}

The judgement by Lord Sumption proceeds on the assumption that authority shows the existence of a doctrine under which a court may pierce the corporate veil under exceptional circumstances (the "doctrine", as Lord Neuberger puts it). It begins with a definition. The doctrine is restricted to cases of "true" veilpiercing. It has to be distinguished from other ways of getting around the separate legal personality e.g. by applying principles of attribution as for example agency or trust. The actual outcome of Prest itself is an example for getting around the legal personality in this wider, looser sense.

"True" veil-piercing is defined by Lord Sumption as disregarding the separate legal personality and identifying the company with its controlling shareholders (sub a). Subsequently, Lord Sumption works out that the only justification to apply the doctrine is the abuse of the corporate legal personality. This is followed by the most contentious part of his judgement, namely the proposition that abuse of the company was only justified under the socalled "evasion principle" as opposed to the "concealment principle" (sub b). According to the evasion principle, it is abuse if controlling shareholders try to evade or frustrate existing legal obligations via the separate legal personality of a company. When judges pierced the corporate veil in mere concealment cases (Trustor v Smallbone; Gencor), they were not right to do so. Finally, Lord Sumption states that veil-piercing is a remedy of last resort (sub c). It can only apply where there is no other legal instrument available to solve the case.

\section{a) The narrow definition of piercing the corporate veil}

Following Lord Sumption, true piercing the corporate veil means disregarding separate corporate personality and identifying the controlling shareholder with the company (or vice versa). Piercing the corporate veil in this strict sense is distinct from other situations where the law may look to the shareholders 
rather than to the company and that have also been referred to as veil-piercing in the past.

Prest, at para. 16: "There is a range of situations in which the law attributes the acts or property of a company to those who control it, without disregarding its separate legal personality. The controller may be personally liable, generally in addition to the company, for something that he has done as its agent or as a joint actor. Property legally vested in a company may belong beneficially to the controller [...] But when we speak of piercing the corporate veil, we are not (or should not be) speaking of any of these situations, but only of those cases which are true exceptions to the rule in Salomon v A Salomon and Co Ltd [1897] AC 22 [...]”

\section{b) What does justify piercing of the corporate veil? - evasion principle vs concealment principle}

Next, Lord Sumption turned to the question of what principle underlies the doctrine of piercing the veil. The generally accepted starting point of his analysis is that English law does not allow the piercing of the veil simply because justice requires so. ${ }^{12}$ Rather, there must be an element of dishonesty.

Prest, at para. 27: "In my view, the principle that the court may be justified in piercing the corporate veil if a company's separate legal personality is being abused for the purpose of some relevant wrongdoing is well established in the authorities. [...] I think that the recognition of a limited power to pierce the corporate veil in carefully defined circumstances is necessary if the law is not to be disarmed in the face of abuse".

This element of dishonesty was formerly known as the "fraud exception". In Trustor, it was said that this applied where the company was a "façade or sham"13 or where the company was involved in some form of impropriety. The latter was qualified in that the impropriety must be, "linked to the use of the company structure to avoid or conceal liability". While Lord Sumption, too, accepted that there must be some kind of wrongdoing, he discarded the traditional "façade"/ "sham" test (if it ever was one) as being too vague. In truth, he argued, the former "façade"/"sham"-cases rested on two different principles: the evasion principle and the concealment principle. However, Lord Sumption was only ready to accept the evasion cases, not the concealment cases as good law. He argued that it had been wrong to pierce the veil for mere concealment, as had happened in Trustor and in Gencor. According to his view, only the evasion or frustration of existing obligations truly justified piercing the corporate veil (Gilford,Jones).

12 See in particular Adams v Cape (n. 8), Trustor v Smallbone and Ben Hashem v Al Shayif (n 10). For older views see e.g. Re a Company [1985] 333, 338 (per Cumming-Bruce LJ).

13 The façade/sham-test went back to a dictum by Lord Keith of Kinkel in Woolfson $v$ Strathclyde Regional Council 1978 SC (HL) 90, at p. 96: “[...] it is appropriate to pierce the corporate veil only where special circumstances exist indicating that it is a mere façade concealing the true facts". 
Prest, at para. 28: "The difficulty is to identify what is a relevant wrongdoing. References to a "façade" or "sham" beg too many questions to provide a satisfactory answer. It seems to me that two distinct principles lie behind these protean terms, and that much confusion has been caused by failing to distinguish between them. They can conveniently be called the concealment principle and the evasion principle. The concealment principle is legally banal and does not involve piercing the corporate veil at all. It is that the interposition of a company or perhaps several companies so as to conceal the identity of the real actors will not deter the courts from identifying them, assuming that their identity is legally relevant. In these cases the court is not disregarding the "façade", but only looking behind it to discover the facts which the corporate structure is concealing. The evasion principle is different. It is that the court may disregard the corporate veil if there is a legal right against the person in control of it [...] and a company is interposed so that the separate legal personality of the company will defeat the right or frustrate its enforcement. Many cases will fall into both categories, but in some circumstances the difference between them may be critical. This may be illustrated by reference to those cases in which the court has been thought, rightly or wrongly, to have pierced the corporate veil". (emphasis added).

Following Lord Sumption, the veil was rightly pierced in Gilford Motors Co v Horne because Horne had used the company as vehicle to competing trade that had been prohibited to him personally and thus frustrated his existing obligation. Likewise, in Jones $v$ Lipman the veil was pierced correctly because Lipman had used the company to escape his existing obligation to convey the property. This observation led Lord Sumption to accept the evasion principle as a valid basis for piercing the veil to counter corporate abuse.

Prest, at para 34: "These considerations reflect the broader principle that the corporate veil may be pierced only to prevent the abuse of corporate legal personality. It may be an abuse of the separate legal personality of a company to use it to evade the law or to frustrate its enforcement".

However, as Lord Sumption immediately clarified in the next paragraph, the evasion principle was the only category that justified piercing the veil.

Prest, at para. 35: "I conclude that there is a limited principle of English law which applies when a person is under an existing legal obligation or liability or subject to an existing legal restriction which he deliberately evades or whose enforcement he deliberately frustrates by interposing a company under his control. The court may then pierce the corporate veil for the purpose, and only for the purpose, of depriving the company or its controller of the advantage that they would otherwise have obtained by the company's separate legal personality". (emphasis added).

Gilford and Jones were distinguished from Gencor and Trustor because in the latter cases, the companies had not been used to evade or frustrate a preexisting liability, but merely to conceal the true recipient of a payment.

In Gencor, the director of a company (one Mr Dalby) had been made accountable for a payment received from a third party. This payment had been directed to his Virgin Island company instead to him personally. Rimer J. found that the Virgin Island company was used as a mere nominee, in a sense 
like Mr Dalby's bank account, and pierced the veil for fraud. According to Lord Sumption, this was not necessary. The company had been used to conceal that in reality, Mr Dalby had received the funds. The law's correct answer to this was not to pierce the veil of the company. Rather, the law would look at the reality of the transaction and attribute the payment to Mr Dalby. The same was true in Trustor where Mr Smallbone had directed the misappropriated funds to a company solely controlled by him.

Lord Sumption held that these two cases were not to be solved by piercing the corporate veil. He gave two reasons. ${ }^{14}$ First, he argued that Mr Dalby (and $\mathrm{Mr}$ Smallbone) would have been responsible in the same way if the payment had been received by a closely connected natural person, e.g. by a spouse. Therefore, the solution could not depend on piercing of the corporate veil. Second, without attribution of the receipt to Dalby/Smallbone, there would not have been any claim to evade at all. The attribution of the receipt by the company to the controller was a prerequisite to establish that there was a prohibited payment at all. Had the companies received monies in their own right, there would have been no restitution. The companies were merely used to conceal that a prohibited payment had been made. They were not abused to evade or frustrate an existing liability.

The latter point was also used by Lord Sumption to explain VTB Capital..$^{15}$ In $V T B$ Capital, a bank financed a transaction that was allegedly at arm's length which, in reality, had been an intragroup transfer. Both companies were under control of one Malofeev. The claimant bank argued that this was fraud and justified the piercing of the corporate veil in order to hold Mr Malofeev personally liable for the loan granted to the buyer company. Both the Court of Appeal and the Supreme Court had rejected this. According to Lord Sumption, veil piercing would have created a new liability that otherwise would not have existed and that nobody had bargained for. There was no evasion of an existing liability by interposition of a company.

\section{c) The rule of last resort}

Finally, Lord Sumption held that true piercing of the corporate veil was only to be applied where no other, more conventional legal instruments were at hand. It was a subsidiary remedy of last resort:

Prest, at para. 35: "The principle is properly described as a limited one, because in almost every case where the test is satisfied, the facts will in practice disclose a legal relationship between the

14 Prest, para 33.

15 Prest, para 34. 
company and its controller which will make it unnecessary to pierce the corporate veil. Like Munby J in Ben Hashem [v Al Shayif [2009] 1 FLR 115], I consider that if it is not necessary to pierce the corporate veil, it is not appropriate to do so, because on that footing there is no public policy imperative which justifies that course. I therefore disagree with the Court of Appeal in VTB Capital [v Nutritek [2012] 2 Lloyd's Rep 313] who suggested otherwise at para 79. For all of these reasons, the principle has been recognised far more often than it has been applied. But the recognition of a small residual category of cases where the abuse of the corporate veil to evade or frustrate the law can be addressed only by disregarding the legal personality of the company is, I believe, consistent with authority and with long-standing principles of legal policy". (emphasis added).

\section{Lord Neuberger}

Lord Neuberger approved the approach of Lord Sumption. Nevertheless, he did not abstain from renewing his fundamental doubts on the existence of legitimate veil-piercing, as he had already expressed in VTB Capital. In particular, he continued to claim that both Jones $v$ Lipman and Gilford $v$ Horne could have been solved in alternative ways, too, as he had done in VTB Capital following Yukong Lines.

VTB Capital, at para. 134 (per Lord Neuberger): “In Gilford [[1933] Ch 935], Mr Horne had undertaken not to compete with his former employer [...] He effectively broke his undertaking by trading through the company, in the same way as if it had been carrying on the competing business through his wife-as indeed had happened in Smith v Hancock [1894] 2 Ch 377, 385, a case relied on by the Court of Appeal in Gilford. Thus, the decision in Gilford had nothing to do with the fact that a company was involved, and therefore, as a matter of logic, the decision cannot have been based on piercing the corporate veil-a point made by Toulson J in Yukong Line [[1998] 1 WLR 294] at 308, and rightly accepted by Arnold J and the Court of Appeal in this case".

Para 135: "The same point (as was said in Yukong Line) applies to Jones v Lipman [[1962] 1 WLR 832] [...]”

While still adhering to the view that those cases could have been solved without piercing the corporate veil, Lord Neuberger was ready to accept in Prest that the judges had assumed they could pierce the veil and that it was appropriate to do so under the narrow circumstances described by Lord Sumption's "evasion principle".

Prest, at para. 69: "On closer analysis [...] it does not appear to me that the facts and outcomes in Gilford Motor and Jones provide much direct support for the doctrine. However, the decisions can fairly be said to have rested on the doctrine if one takes the language of the judgments at face value. Further, they indicate that, where a court is of the view (albeit that I think that it was mistaken in those cases) that there is no other method of achieving justice, the doctrine provides a valuable means of doing so".

In the end, this brought him to recognise that English law contained a doctrine of veil-piercing as a remedy of last resort. Moreover, he followed the distinc- 
tion drawn by Lord Sumption between evasion and mere concealment and recognised only the former as legitimate veil-piercing.

Prest, at para. 79: “[...] I was initially strongly attracted by the argument that we should decide that a supposed doctrine, which is controversial and uncertain, and which, on analysis, appears never to have been invoked successfully and appropriately in its 80 years of supposed existence, should be given its quietus".

Para. 80: "However, I have reached the conclusion that it would be wrong to discard a doctrine which, while it has been criticised by judges and academics, has been generally assumed to exist in all common law jurisdictions, and represents a potentially valuable judicial tool to undo wrongdoing in some cases, where no other principle is available. [...] I believe that it would be right to adopt it as a definition of the doctrine". (emphasis added).

Para. 81: "Having read what Lord Sumption JSC says in his judgment, especially in paras 17, $18,27,28,34$ and 35 , I am persuaded by his formulation in para 35, namely that the doctrine should only be invoked where "a person is under an existing legal obligation or liability or subject to an existing legal restriction which he deliberately evades or whose enforcement he deliberately frustrates by interposing a company under his control"." (emphasis added).

Lord Neuberger explicitly accepted the proposed rule of last resort:

Prest, at para. 62: "Furthermore, I agree that, if the court has power to pierce the corporate veil, Munby J was correct in Ben Hashem v Al Shayif [2009] 1 FLR 115 to suggest that it could only do so in favour of a party when all other, more conventional, remedies have proved to be of no assistance (and therefore I disagree with the Court of Appeal in VTB [2012] 2 Lloyd's Rep 313, para 79, who suggested otherwise)”.

\section{Lady Hale (with whom Lord Wilson agreed)}

Lady Hale (with whom Lord Wilson agreed) delivered the most pronounced counter-opinion to Lord Sumption's restatement. She, too, recognised the existence of a doctrine to pierce the corporate veil. Moreover, she accepted that Gilford and Jones rested on evasion of existing obligations. But she neither held that the two categories of evasion and concealment introduced by Lord Sumption were exhaustive nor that only evasion justified piercing of the corporate veil. According to her, these categories were rather to be understood as examples of the underlying principle to prevent companies from being used as "engines of fraud". To underpin her point, she referred to Re Darby. The rejection of veil-piercing in Salomon was explained by her through the fact that the House of Lords, unlike the courts below, did not hold that the running of a sole trader business via a company was such an illicit advantage. ${ }^{16}$

16 Prest, at para. 90: “[...] In Salomon v A Salomon \& Co Ltd [1897] AC 22 the purpose was to go behind the separate legal personality of the company in order to sue Aaron Salomon personally for a liability that was legally that of the company which he had set 
Prest, at para. 89: “[...] The question nevertheless arises as to whether, in a case such as this, the courts have power to prevent the statutes under which limited liability companies may be established as separate legal persons, whether in this or some other jurisdiction, being used as an engine of fraud. I agree with Lord Sumption that "piercing the corporate veil" is an example of that general principle $[. .$.$] ” (emphasis added).$

Para. 91: "But there are a few cases where the courts have apparently been prepared to disregard the separate personality of a company in order to grant a remedy, not only against the company, but also against the individual who owns and/or controls it. Both Gilford Motor Co Ltd v Horne [1933] Ch 935 and Jones v Lipman [1962] 1 WLR 832 are examples of this. In both those cases, it so happened that the controller had a pre-existing legal obligation which he was attempting to evade by setting up a company, in the one case a contractual obligation not to compete with his former employers, in the other case a contractual obligation to sell some land to the claimant. In In re Darby [1911] 1 KB 95, on the other hand, the liquidator of a creditor company was permitted to go behind the separate personality of a debtor company registered in Guernsey in order to obtain a remedy personally against its promoters who had fraudulently creamed off the profit from the sale by the Guernsey company to the creditor company of a worthless licence to run a slate quarry in Wales". (emphasis added).

Para. 92: "I am not sure whether it is possible to classify all of the cases in which the courts have been or should be prepared to disregard the separate legal personality of a company neatly into cases of either concealment or evasion. They may simply be examples of the principle that the individuals who operate limited companies should not be allowed to take unconscionable advantage of the people with whom they do business". (emphasis added).

Finally, Lady Hale referred to Stone $E$ Rolls $v$ Stephen Moore (a firm) as an example for "going behind the separate legal personality".

At para. 95: "Stone E Rolls Ltd v Moore Stephens (a firm) [2009] AC 1391 is an example of going behind the separate legal personality of the company in order to "get at" the person who owned and controlled it, not for the purpose of suing him, but in order to attribute his knowledge to the company so that its auditors could raise a defence of ex turpi causa to the company's allegation that they had negligently failed to detect the fraudulent nature of its business".

This was a case on a Ponzi scheme with banks lending on fictitious transactions. The fraud had been committed by the sole beneficial owner of the company (Stone \& Rolls Ltd) who was both its director and its only directing will and mind. After the discovery of the fraud, the banks, standing in the

up [...] This succeeded at first instance and in the Court of Appeal, Lindley LJ going so far as to say that "Mr Aaron Salomon's scheme is a device to defraud creditors": [1895] 2 Ch 323, 339. They did not think that Parliament had legislated for the setting up of limited liability companies in order that sole traders should be able to conduct their businesses on limited liability terms. But the House of Lords disagreed. [...] They did not think that there was any fraud involved simply in using a limited liability company as a vehicle for conducting a legitimate business [...]”. 
shoes of the company, sued its auditors for negligently not detecting this fraud. The case turned on whether or not allowing the auditors the illegality defence, arguing that the fraudulent acts of the directing will and mind were to be attributed to the company, thus turning it from victim to tortfeasor who cannot sue on the basis of his own tort. The majority of the House of Lords held so. From a doctrinal perspective, the case rested on a (highly contentious) exception from applying the directing will and mind doctrine as an attribution rule. Nevertheless, in substance, it raised the question whether the separate personality of the company should be overcome and Stone \& Rolls Ltd be equated with its wrongdoing owner or not. By referring to this case in her speech, Lady Hale arguably shows that she continues to understand the concept of piercing the corporate veil in the older, looser sense of the term, including all ways to go past the separate legal personality, and that she does not adopt the new, restricted meaning that was given to it by Lord Sumption. The underlying claim of Lady Hale appears to be that the principle of the doctrine of piercing the veil is wider than proposed by Lord Sumption. It shall counter corporate abuse. According to her, the evasion cases Gilford and Jones certainly mark one case of abuse. But it is not the only case.

\section{Lord Mance}

Lord Mance approved Lord Sumption's approach in principle.

Prest, at para. 98: "I agree with Lord Sumption's analysis of the domestic case-law to date in which the metaphor of "piercing the veil" has been deployed as part of the reasoning for a decision representing an exception to the basic principle in Salomon v A Salomon \& Co Ltd [1897] AC 22".

He also appears to follow Lord Sumption's views on the evasion principle and the concealment principle.

Prest, at para. 99: "In the upshot, the only cases which Lord Sumption identifies in which a principle of 'piercing the veil' can be said to have been critical to the reasoning can be rationalised as falling within what he describes as the evasion principle. In other cases, the corporate entity was simply being used to conceal the real actor, or some other analysis or relationship existed (such as principal and agent, nominee or trustee-beneficiary) to explain the decision".

However, he is not prepared to hold that only the evasion principle justifies true piercing of the corporate veil:

Prest, at para. 100: "It is however often dangerous to seek to foreclose all possible future situations which may arise and I would not wish to do so". (emphasis added).

As an example for other cases where veil-piercing might be appropriate he refers to what he had stated in a antecedent Privy Council judgement (in a 
context where Gécamines was a state corporation, not susceptible of being wound up).

La Générale des Carrières et des Mines Sarl v Hemisphere Associates LLC (Jersey) [2012] 2 Lloyd's Rep 443 at para. 77: "The alternative way in which Hemisphere puts its case is to submit that, if Gécamines is otherwise accepted as a separate juridical entity, the facts found justify the lifting of the corporate veil to enable Hemisphere to pursue Gécamines as well as the state. In the Board's view, this involves a misapplication of any principles on which the corporate veil may be lifted under domestic and international law. Assuming for the sake of argument that the "unceremonious" subjecting of Gécamines to the controlling will of the state involved a breach by the state of its duty to respect Gécamines as a separate entity, that might conceivably justify an affected third party, possibly even an aggrieved general creditor of Gécamines, in suggesting that the corporate veil should be lifted to make the state, which had deprived Gécamines of assets, liable for Gécamines' debts".

Finally, Lord Mance appears to agree with Lord Sumption that veil-piercing is a remedy of last resort:

Prest, at para. 100: "What can be said with confidence is that the strength of the principle in Salomon's case and the number of other tools which the law has available mean that, if there are other situations in which piercing the veil may be relevant as a final fall-back, they are likely to be novel and very rare". (emphasis added).

\section{Lord Clarke of Stone-cum-Ebony}

Lord Clarke of Stone-cum-Ebony accepted the existence of a doctrine of piercing the corporate veil and the rule of last resort:

Prest, at para. 103: "I agree that there is such a doctrine and that its limits are not clear. I also agree that Munby J was correct in Ben Hashem v Al Shayif [2009] 1 FLR 115 to suggest that the court only has power to pierce the corporate veil when all other more conventional remedies have proved to be of no assistance. It is thus likely to be deployed in a very rare case". (emphasis added).

Like Lord Mance, he rejected the proposition that only evasion of existing obligations justified piercing of the veil. However, differing from Lord Mance, he did not subscribe to the categories of evasion and concealment at all.

Lord Sumption may be right to say that it will only be done in a case of evasion, as opposed to concealment, where it is not necessary. However, this was not a distinction that was discussed in the course of the argument and, to my mind, should not be definitively adopted unless and until the court has heard detailed submissions on it. I agree with Lord Mance that it is often dangerous to seek to foreclose all possible future situations which may arise and, like him, I would not wish to do so. (emphasis added) 


\section{Lord Walker of Gestingthorpe}

Lord Walker of Gestingthorpe did as no other member of the Supreme Court did: he did not recognise the existence of a doctrine of piercing the corporate veil at all. Consequently, he neither followed the distinction between evasion and concealment nor accepted the exclusiveness of the former.

Prest, at para 106: "I am reluctant to add to the discussion but for my part I consider that "piercing the corporate veil" is not a doctrine at all, in the sense of a coherent principle or rule of law. It is simply a label-often, as Lord Sumption observes, used indiscriminately - to describe the disparate occasions on which some rule of law produces apparent exceptions to the principle of the separate juristic personality of a body corporate reaffirmed by the House of Lords in Salomon v A Salomon \& Co Ltd [1897] AC 22. These may result from a statutory provision, or from joint liability in tort, or from the law of unjust enrichment, or from principles of equity and the law of trusts [...] They may result simply from the potency of an injunction or other court order in binding third parties who are aware of its terms. If there is a small residual category in which the metaphor operates independently no clear example has yet been identified, but Stone E Rolls Ltd v Moore Stephens (a firm), mentioned in Lady Hale's judgment, is arguably an example". (emphasis added).

However, the last sentence of his speech, containing the reference to Stone $\mathcal{E}$ Rolls, could be understood in a way that he has not have ruled veil-piercing out completely, but would eventually have been ready to accept it as a "residual" remedy in exceptional circumstances.

\section{Summarising the will of the Justices}

Lord Sumption attempted to fundamentally restate the law on piercing the corporate veil. But he did not entirely succeed in doing so due to the only hesitant acceptance by his peers. That is however neither to say that the law is not settled at all nor that there can be no principles drawn from what is accepted as the law now. Arguably, the following three propositions can be taken safely as the new law according to the will of the Justices, while the fourth one, concerning the crucial point of the scope of the principle, is undecided.

\section{a) A doctrine of piercing the veil exists under English law}

After more than a century, this finally qualifies the Salomon principle. Only Lord Walker of Gestingthorpe disagreed to that proposition. By contrast, Lord Neuberger explicitly endorsed it, after still being the doubting Thomas of the Supreme Court in VTB Capital. 
b) Piercing the veil is a remedy of last resort, i.e. it is not appropriate to pierce the veil where it is not necessary to do so

The rule of last resort is accepted by all judges, arguably even by Lord Walker of Gestingthorpe who speaks of a small residual category where the doctrine might work independently. This rule buries the remedy in practice. It may well have been the "teaser" to make Lord Neuberger accept the doctrine as a legal principle after all.

From a practical perspective, this is the most important principle stated by Prest because it curtails the scope for eventual veil-piercing down to a margin which is close to zero. In today's world, the law tackles most situations where companies can promote mischief in a satisfactory way. For example, sanctions against rogue states explicitly extend to foreign subsidiaries controlled by the citizens (corporate or natural) of that state. No more need to re-run Daimler. ${ }^{17}$ Therefore, the failure of Prest to clarify the exact scope of the principle (evasion or abuse?) that will be discussed in the following is theoretically important, but will not haunt practice any longer.

\section{c) Piercing the veil is justified under the evasion principle}

The majority of the Supreme Court justices supports this proposition, which was based on the analysis of the previous case law by Lord Sumption. Lord Neuberger and Lord Mance explicitly subscribe to the principle. Lady Hale (with whom Lord Wilberforce agrees) accepts both the cases and the evasion explanation put forward. However, Lord Clarke of Stone-cum-Ebony did not subscribe to the category of evasion. The same is of course true for Lord Walker of Gestingthorpe. Nevertheless, we have a clear majority ruling that the evasion principle triggers piercing the veil. As a result, Prest has spelt out a readily applicable rule of law.

d) The evasion principle is not exhaustive, but it is the only case of piercing the veil for corporate abuse that is spelt out yet and other cases will be rare

The main issue that was left undecided by Prest is whether piercing the veil is only triggered by evasion (evasion principle) or whether the category of evasion is only a prominent case of a wider principle to pierce the veil in cases of corporate abuse. It is necessary to derive the valid statement of the law on that point by close scrutiny of the opinions and head counting. 
Lord Sumption and Lord Neuberger clearly stated that only evasion justifies piercing the veil. By contrast, Lady Hale elaborated that the underlying principle was to prevent corporate abuse, i.e. companies being made engines of fraud. Lord Mance adopted the analysis of Lord Sumption, but explicitly rejected his claim for exclusiveness of the evasion principle. Lord Clarke of Stone-cum-Ebony did not even accept the categories. And Lord Walker of Gestingthorpe, as seen, did not even accept any doctrine of piercing the veil at all.

Therefore, we must conclude that the proposed (re)statement by Lord Sumption that only evasion triggers piercing the veil is not accepted as the law. But does this necessitate the interpretation that the Supreme Court adopted the wider view according to which the veil will be pierced for corporate abuse, in order to - like Lady Hale has put it "prevent companies being used as engines fraud"?

This does not seem to be the case. True, Lord Sumption held that evasion constitutes corporate abuse (at para. 34, see above). But according to his view, only evasion is abuse that triggers piercing the veil under the "limited principle" that he proposed (at para. 35, see above). The same is true for Lord Neuberger, notwithstanding the fact that in his view, the evasion principle formed part of the larger principle that "fraud unravels everything". Both made it very clear that they saw no other cases of legitimate veil-piercing. In their view, evasion constitutes abuse, but evasion, not abuse is the trigger. Even though this was not accepted by the majority, it is not possible to turn their words in their mouths around and make them accept that instead of evasion, the vague notion of corporate abuse should trigger piercing the veil. This would even fall back behind the starting point of their opinion, namely that the required "impropriety" could not be found by the façade/sham test.

Lord Mance and Lord Clarke of Stone-cum-Ebony support the evasion principle, but oppose any strict limitation of the doctrine to it. But that is not to say that they follow Lady Hale's wide approach instead. Indeed, they neither openly or impliedly subscribe to a more general doctrine of piercing the veil for corporate abuse. They only want to leave the door open for the remedy if an exceptional case of a particular kind of abuse came up and could not be tackled by conventional remedies (like for example the asset shifting that took place in La Générale des Carrières et des Mines Sarl in a company that could not be wound up in liquidation).

This leads to the following conclusion:

- Evasion constitutes corporate abuse. But the trigger for the remedy of piercing the veil is the limited evasion principle, not the wider notion of corporate abuse. 
- The evasion principle is not the only case that justifies piercing the veil for corporate abuse. But after Prest, it is the only case that is spelt out and readily applicable.

- Subject to the rule of last resort, other cases of corporate abuse may give rise to the remedy in future, too. But they will be rare and are not spelt out yet. Prest offered no test for them. The façade/sham test has been discarded, but has not been replaced.

\section{Criticism of Prest}

Prest was a great achievement that pushed the law of piercing the veil into the $21^{\text {st }}$ century. In particular, it must be praised for abolishing the façade/shamtest of the former "fraud exception". This approach to piercing the veil was based on the archaic notion of the company as a mere fiction that concealed the truth and could be ignored wherever necessary. In truth, there is no concealment, let alone abuse, in the legal personality of a company. It is as much a reality as a contract, a right or even an idea. It must be taken seriously, not only for the benefit of all stakeholders, but simply to obey the law.

However, the judgement suffers from the typical flaws and logical inconsistencies of a compromise. Prest wanted to avoid the complete abolition of the remedy by curtailing it back to practical irrelevance. But as will be shown in the following, this does not pass the test of reason because the principles underpinning the doctrine of piercing the veil necessarily carry further than to evasion, so that the doctrine must either be extended or eliminated.

\section{Why only evasion?}

The most fundamental point criticism that can be raised against the limitation of piercing the veil to the evasion principle is that there are no persuasive reasons given for it. It looks like an arbitrary limitation made up with the evident purpose of keeping the doctrine at bay as tightly as possible. Even if we accept Lord Sumption's analysis that the veil was only pierced correctly in Jones $v$ Lipman and Gilford v Horne but not so in Trustor and Gencor, and even if we concede that this was so because the latter two cases concerned mere concealment (but see below), this does not carry the conclusion that only evasion can be corporate abuse. To the contrary, most lawyers would see evasion as one example of the wider principle to prevent corporate abuse. Indeed, this is Lord Sumption's own starting point. He justifies the recognition 
of the doctrine because, in his word, "it is necessary if the law is not to be disarmed in the face of abuse". But he does not explain why evasion should be the only case of corporate abuse. This has been recognised in for example the US where the Supreme Court ensured a corporation could not "evade its responsibilities"; the court extended the corporate president's actual knowledge to the corporate body. ${ }^{18}$ And this is the better view. The law is made by cases, but built on principles, and there may well be other cases of abuse out there that may come up in future. In fact, Re Darby, to which Lady Hale referred, provides a good example. The company was obviously set up by the fraudsters to conceal their involvement to the market. But while concealment was involved and certainly facilitated the fraudulent scheme, it was not at the heart of the case. Had the hidden incorporators come back from their road to Damascus and intended to start a second, good life by embarking on an honest venture, nobody would have considered piercing the veil for mere concealment, even if this venture had eventually failed. But they intended to use the company as engine for yet another fraud from the outset, and that was the true trigger for the piercing of the veil that had taken place by skimming the profits. There can be hardly any objection against the outcome of this case. But it is certainly not an evasion case. This shows that it is not persuasive to limit piercing the veil for corporate abuse strictly to evasion cases, and even less so simply because of a thesis that up to now, only these were the "correct" piercing cases.

18 J.J. McCaskill Co. v. U.S., 216 U.S. 504 (1910). Cf. further the summaries of the US case of the $19^{\text {th }}$ and early $20^{\text {th }}$ century by Wormser and Fuller:

Wormser, Piercing the Veil of the Corporate Entity, 12 Colum. L. Rev. 496, 517 (1912): "What general rule, if any, can be laid down? The nearest approximation to generalization which the present state of the authorities would warrant is this: When the conception of corporate entity is employed to defraud creditors, to evade an existing obligation, to circumvent a statute, to achieve or perpetuate monopoly, or to protect knavery or crime, the courts will draw aside the web of entity, will regard the corporate company as an association of live, up-and-doing, men and women shareholders, and will do justice between real persons."

Fuller, The Incorporated Individual: A Study of the One-Man Company, 51 Harv. L. REv. 1373, 1402 (1938): "This group is composed of cases in which the corporate device has been used to defraud creditors, to evade existing obligations, to circumvent a statute, to achieve or perpetuate a monopoly, or to protect knavery or crime. It has been held that the corporate device, whether a one-man company or a multi-shareholder company, may not be used successfully for such ends." 


\section{Are Trustor and Gencor in truth evasion cases?}

Contrary to the assumption of Lord Sumption, the evasion principle may cover both Trustor and Gencor. According to Lord Sumption, in both cases the liability (to restore the payment) would not have arisen at all without the antecedent attribution of the receipt of the payment by the company to the controlling shareholder. Therefore, the interposition of the dummy companies did not evade a pre-existing obligation.

But this looks at the cases from too narrow a perspective. In truth, there was a pre-existing (fiduciary) duty in both Trustor and Gencor: The duty not to effect the unlawful payments. The controllers sought to frustrate this pre-existing duty by interposing the companies. This was, of course, done in order to conceal their personal involvement. But it was not done for "mere concealment", but also for the frustration of the existing prohibition, i.e. for evasion. In Gencor, Mr Dalby, the director of ACP, made his company pay an unlawful commission to his dummy company, Burnstead. The (bold) argument put before Rimer J went: Mr Dalby owed a fiduciary duty to ACP, but he did not receive the payment, while the actual recipient of that payment, i.e. his dummy company, Burnstead, owed no fiduciary duty to ACP. Therefore, the payment was not unlawful. ${ }^{19}$

This argument was of course flawed because under the laws of agency, the payment to Dalby's dummy company was attributed to him personally, and so he actually did receive the payment and breach his duty. However, flawed or not, the argument shows that the dummy company was not merely used for concealment, but for an attempt to frustrate the pre-existing fiduciary duty of the director. The same can be said about Trustor.

At the end of the day, it still holds true that neither Trustor nor Gencor should have been solved by piercing the veil. But this was not because they are about mere concealment but because there was a more conventional remedy at hand, namely attributing the payments to the controlling shareholders under the general laws of agency because the companies did not receive the payments in their own right.

19 See Gencor, per Rimer J: "Mr Francis submitted that even if he was otherwise wrong on his argument, there is still no one who was, is or can be accountable to ACP for the commission. Mr Dalby is not accountable because he did not receive it: it went straight into Burnstead, albeit at Mr Dalby's direction. Burnstead is not accountable because, although it received the commission, it was and is not in a fiduciary relationship with ACP.” 


\section{Are even Yukong Line and Creasey evasion cases?}

The evasion principle may even cover Yukong Line, ${ }^{20}$ thereby implicitly disapproving the reasoning by Toulson J, and Creasey $v$ Breachwood, ${ }^{21}$, thereby implicitly reversing the overruling of that case in Ord v Belhaven Pubs. ${ }^{22}$

In Creasey $v$ Breachwood, the business of company A was informally transferred to company B by the controllers of both companies. This was deliberately done to frustrate an existing obligation directed to company A. In Yukong Line, assets were shifted in a very similar way by the controlling shareholder, one Mr Yamvrias, from one company to other members of his group in order to frustrate an existing claim by Rendsburg against that company.

The evasion principle implies that those two cases would have justified piercing the corporate veil. That would mean that, save for the rule of last resort, Creasey became good law again whereas Yukong Line was now bad law. Additional support for this disturbing proposition can be drawn from the fact that Yukong Line was based on the reasoning that neither Gilford nor Jones involved piercing of the corporate veil - while the majority of the Supreme Court now held otherwise.

Yukong Line v Rendsburg (The Rialto)[1998] 1 W.L.R. 294, 308 (per Toulson J): “The present case differs from Jones v. Lipman [1962] 1 W.L.R. 832 and Gilford Motor Co. Ltd. v. Horne [1933] Ch. 935, where equitable relief was granted against the company being used to perpetrate a continuing breach of contract by its controller, of which the company had full knowledge. If either Mr. Horne's wife or Mr. Lipman's wife (assuming their existence) had agreed to act in a similar role to that of company, no doubt similar equitable relief would have been granted against the lady concerned. Salomon's case [1897] A.C. 22 would have been irrelevant. In the same way, the fact that the company had separate legal personality was no bar to the court granting relief against it as well as the contract breaker".

To be sure, the exact wording of the definition by Lord Sumption does not cover Creasey and Yukong Line. Lord Sumption speaks of "a person under an existing legal obligation ... which he deliberately evades or frustrates by interposing a company under his control". This obviously refers to the natural persons (Horne, Lipman) that had used dummy companies to shrug off the shackles of their existing duties. But there is no decisive difference between natural and legal persons in this respect. Both in Creasey and in Yukong Line we see legal persons under existing obligations. Plus, there were (other) companies interposed to hide away the assets in order to frustrate that

20 Yukong Line Ltd. of Korea $v$ Rendsburg Investments Corporation of Liberia and Others (No. 2) [1998] 1 W.L.R. 294.

21 [1992] B.C.C. 638.

22 [1998] 2 B.C.L.C. 447. 
obligation. However, the company under the existing obligation was not itself interposing the other company to frustrate its obligation. Instead, this was done by the controlling shareholder, respectively, of both companies who was not personally liable under the obligation he sought to evade. This is not in line with the wording of Lord Sumption's definition. The definition of the evasion principle requires that the obligated person and the "interposer" are identical. This would only be complied with if the debtor companies of Creasey and Yukong had transferred the assets to a subsidiary under their own control instead to a sister company.

Now does this tiny difference matter or is it purely technical and, thus, negligible? From a company law perspective, it surely matters. If the assets are transferred to a subsidiary of the debtor company, the creditors are not deprived because they could still seize the shares of the sub. This is not the case if the assets are transferred to sister companies.

However, this is exactly why the asset shifting to a sister company constitutes an even worse case of frustration of an existing liability. If the evasion principle is the law's answer to the malevolent frustration of existing liabilities by the abusive interposition of companies, Creasey and Yukong must be covered in the same way. Like cases must be treated alike. There is no difference as to whether the frustrated legal duty was a personal duty of the controlling shareholder or a duty of a company he controls. Nor does it matter whether he transfers one particular asset to frustrate a claim for specific performance (like in Lipman) or whether he transfers all assets to frustrate an ordinary claim (like in Creasey and Yukong Line).

Traditional remedies like fraudulent trading, fraudulent conveyances or actio Pauliana show that this sort of conduct is indeed generally perceived as fraud. The fact that insolvency law has its own, well-established remedies against this kind of fraud against creditors in place only shows that piercing the veil will most of the time be barred by the rule of last resort. Nevertheless, the evasion principle as stated by Prest re-opens the door for using piercing the veil against asset shifting.

\section{Conflict with VTB Capital?}

The approval of Jones $v$ Lipman and Gilford $v$ Horne inevitably conflicts with VTB Capital. In VTB Capital, Lord Neuberger made the argument that piercing the veil could not be used to extend a contractual liability to a noncontracting party because the parties of the contract had not bargained for that. This view was explicitly confirmed by Lord Sumption in Prest. 
VTB Capital, at para 132 (per Lord Neuberger): "In so far as VTB invokes the principle of piercing the veil of incorporation, its case involves what [...] may be characterised as an extension to the circumstances where it has traditionally been held that the corporate veil can be pierced. It is an extension because it would lead to the person controlling the company being held liable as if he had been a co-contracting party with the company concerned to a contract where the company was a party and he was not. In other words, unlike virtually all the cases where the court has pierced the corporate veil, VTB is claiming that Mr Malofeev should be treated as if he were, or had been, a co-contracting party with RAP under the two agreements, even though neither Mr Malofeev nor any of the contracting parties (including VTB) intended Mr Malofeev to be a party".

See also Prest, para. 34 (per Lord Sumption): “[...] Thus in a case like VTB Capital [v Nutritek [2012] 2 Lloyd's Rep 313; [2013] 2 AC 337], where the argument was that the corporate veil should be pierced so as to make the controllers of a company jointly and severally liable on the company's contract, the fundamental objection to the argument was that the principle was being invoked so as to create a new liability that would not otherwise exist. The objection to that argument is obvious in the case of a consensual liability under a contract, where the ostensible contracting parties never intended that any one else should be party to it".

For a start, the reservation of Lord Neuberger in VTB Capital against extending the corporate liabilities of the controlling shareholder is well-founded. English Courts have never really accepted piercing the veil as a means to bypass the company and get into the pockets of the controlling shareholders in order to cover corporate debts. No case actually or potentially opening up that line survived for long. ${ }^{23}$ This is in stark contrast to jurisdictions like the US or France where extending the corporate liabilities to the shareholders is seen as the main purpose of veil-piercing exercises. Nevertheless, there is a sound policy behind the English approach. Piercing the veil in dummy cases like Jones $v$ Lipman or Gilford $v$ Horne only goes around the separate legal personality. Piercing the veil to extend corporate debts to the shareholders also undermines the limitation of liability. Thus, it jeopardises the very purpose of companies. Companies are designed to facilitate trading by limiting risk and shielding the assets of both the owners and the entity. They are not designed to create obedient dummies.

But be that as it may, the crucial point here is that the evasion principle inevitably collides with the (alleged) rule against extending contractual debts to non-contracting parties. If the rule is that contractual liabilities must never be attached to non-contracting parties, evasion cannot trigger piercing the veil. Following that approach, Yukong Lines was right and Jones $v$ Lipman and Gilford $v$ Horne were wrong because in both of these cases the

23 The dictum of Re a Company by Cumming-Bruce (n. 12) did not survive Adams v Cape (n. 10); Creasey v Breachwood (n. 20) was soon overruled by Ord v Belhaven (n. 21); Gramsci by Burton J was disapproved by Lord Neuberger in VTB Capital (n. 2), and finally, Trustor was re-solved by Prest (see above, sub I 2 b). 
dummy companies were subjected to contractual obligations without being party to the contracts that had been concluded by their controlling shareholders. Conversely, if evasion triggers piercing the veil to extend personal obligations of the controlling shareholder to his dummy company, the same must work the other way round and the argument of VTB Capital is wrong.

\section{Why evasion at all?}

A final objection goes into the opposite direction. Even the very limited acceptance of piercing the veil by the Supreme Court may have gone too far. It is generally accepted that English law does not recognise a doctrine of preventing fraus legis or fraude à la loi. It has good reasons to do so. Where does evasion start? If the pedestrian lights show red and I cross the street $1 \mathrm{~m} / 10 \mathrm{~m} /$ $50 \mathrm{~m}$ away from the crossing, am I still an offender? If the traffic lights at the junction show red and I take a "shortcut" via the petrol station at the corner, am I an offender (like in the US) or simply clever? What if you do not want to sell your land to me, but I am able to make a friend buy it from you and sell it on to me. Salomon says: If the law requires seven persons to set up a company, and I use six dummies to end up with a de-facto one-man company, I am clever. So where is the difference if the covenant in the contract says I must not compete with you, and I am so smart to use a company to do so.

If we look at the cases from this perspective, not only Trustor and Gencor, but also Lipman and Gilford may have been wrongly decided in the long shadow of the Salomon principle. These evasion cases do not seem to be about fraud. They are rather about acting in good faith. There is no general duty of acting in good faith under English law. England has introduced the principles of Equity instead. This is the place where the decision whether or not to help must be made. Further support for this view can be found in the reasoning by Toulson $\mathrm{J}$ in Yukong Line.

\section{Corporate abuse as the wider principle?}

If evasion is accepted as a case of corporate abuse, and if the majority of the Supreme Court holds that evasion is not exhaustive, this begs the question whether the better view is to conclude that the doctrine of piercing the corporate veil rests on the wider notion of corporate abuse. It is submitted that the answer to this should be: No! Resorting to the general notion of corporate abuse would be worse than going back to square one because it would introduce the very general concept that exists (and has been tamed!) in other 
jurisdictions but was never accepted in the UK. The judgement gives no guidance on that, not even after the façade/sham test had been discarded by Lord Sumption and the proposed limitation to evasion had been ejected. There would be no merits in replacing the façade/sham-test by the much broader and indistinct category of corporate abuse. To do so would require a distinction between use and abuse of companies that is even more difficult than finding "evasion". This line would have to be drawn through the entire business conduct of corporations. It would be up to practice, drawing from both precedent and legal comparison, to contain the scope of that principle by establishing new categories of corporate abuse like e.g. fraudulent corporate schemes (Re Darby), asset shifting (Gecamines), severe underfunding, or "strangling" subsidiaries within corporate groups.

At the end of the day, practice could be haunted by a broad notion of corporate abuse as trigger for piercing the corporate veil; limited liability could be undermined. Of course, these negative effects would be mitigated if the rule of last resort fulfilled the role it was designed for and led to a de-facto abolition of the remedy. But as will be seen next, this is not necessarily the case.

\section{The unclear scope of the rule of last resort}

The rule of last resort states that piercing the veil is a residual remedy. It shall not lie where more conventional remedies are at hand. As shown above, Lord Sumption explained this by reference to Trustor and Gencor. In both cases, he said it would not have been necessary to pierce the veil because the payments to the dummy companies could be attributed to the controlling shareholder under the general laws of agency. This is true, but this is only academic. The outcome of the case would not have changed by not resorting to piercing the veil. One might well ask the question why there should not be two parallel remedies at the hands of the claimant. Cui bono? The same observation applies in Prest, too. The Supreme Court goes down a very long and winding road to deny piercing the veil, just to hold unanimously that the laws of trust lead to the very result the claimant spouse wanted to achieve.

Indeed, the proposed rule only seems to state that, "if it is not necessary to pierce the corporate veil, it is not appropriate to do so", ${ }^{24}$ i.e. that a court, "could only do so in favour of a party when all other, more conventional remedies have proved to be of no assistance". ${ }^{25}$ Framed that way, the rule of 
last resort is only academic. It surely bars piercing the veil for the sake of legal certainty where other remedies apply. But does it also prevent piercing the veil where this is not the case? As the rule stands now, it cannot exclude piercing the veil to the full extent necessary to save practice from legal uncertainty. Take for example the malicious asset shifting that took place in Yukong Line or Creasey ${ }^{26}$ It is obvious that such insolvency-related misconduct should be primarily tackled by sections 213 and 214 Insolvency Act 1986. Disgruntled creditors cannot sue the asset-shifting director or shareholder directly, but are left to calling for the liquidator. The direct claim under section 423 Insolvency Act 1986 is accordingly restricted, see sections 424(1)(a) - (c) Insolvency Act 1986. Clearly, piercing the veil should not be available to leapfrog these provisions. But this means that piercing the veil cannot only be barred where a more conventional remedy of the claimant against the defendant will succeed. There may also be cases where the law does not want to grant a remedy, conventional or non-conventional, at all.

A related issue is whether the rule bites where the more conventional remedy is not available against the defendant, but against a third party. This seems to be the interpretation of the rule of last resort by Lord Neuberger. According to his view, it was not necessary to pierce the veil of Lipman's company directly because under the equitable rules of specific performance, Jones could as well have sued Lipman for procuring the retransfer of the land from his company to himself. ${ }^{27}$ Following that, the claim against Lipman's company should have been dismissed and Jones should only have sued Lipman personally. If this is true, the rule of last resort is not merely academic any more. Its scope is considerably wider. This may be helpful for legal certainty. However, there is a trade off with justice. Notwithstanding the uncertainties of the principle set out above, we must bear in mind that the corporate veil can only ever be pierced for conduct that amounts to impropriety/corporate abuse. If veil-piercing is denied because more conventional remedies against third parties were available, this will create a risk for the victim of suing the wrong defendant at first, then suing the right defendant too late, and finally failing altogether - and this for the benefit of a fraudster?

On a side note: Since Lord Neuberger thinks that Gilford could also have been solved by the principles of agency, ${ }^{28}$ we cannot know whether Jones and Gilford are good law, notwithstanding that Lord Sumption insisted that they were correctly solved by piercing the veil. Lord Neuberger tried to escape this

26 Above, n. 19 and 20.

27 Prest, at para 73 (per Lord Neuberger).

28 Prest, at para 71 (per Lord Neuberger). 
dilemma by establishing a kind of "subjective test" for the rule of last resort. According to his view, piercing the veil was permissible where judges thought (rightly or not) that they had no choice but to pierce the veil to do justice and counter abuse. ${ }^{29}$ But this contradicts the application of the rule by Lord Sumption who clearly re-judged Trustor and Gencor on an objective basis when he held that the judges should have applied agency law instead of piercing the corporate veil.

\section{Conclusion}

The law on piercing the veil after Prest stands as follows:

a) A doctrine of piercing the veil exists under English law

b) Piercing the veil is a remedy of last resort, i.e. it is not appropriate to pierce the veil where it is not necessary to do so

c) Piercing the veil is justified under the evasion principle

d) The evasion principle is not exhaustive, but it is the only case of piercing the veil for corporate abuse that is spelt out yet and other cases will be rare

Despite the broad consensus in Prest, severe doubts overshadow the validity of the evasion principle. The evasion principle is based on the prevention of corporate abuse. Therefore, piercing the veil cannot be limited to evasion cases. It must e.g. extend to cases of fraudulent corporate schemes (Re Darby) and even to asset shifting, too, because like cases must be treated alike. Conversely, if the law states that contractual debts cannot be extended to non-contracting parties, as held in VTB Capital and confirmed in Prest, the courts were not right to pierce the veil in Jones $v$ Lipman and Gilford $v$ Horne. If this is true, evasion cannot trigger piercing the veil at all. Also, it is far from clear why evasion of individual obligations should trigger piercing the veil if evasion of the general law does not.

In light of the various inconsistencies analysed above, it appears preferable from a theoretical standpoint to either extend the doctrine to cover all cases of "corporate abuse" or to abolish it after all. The latter approach would last but not least be well in line with the development in Germany where the concept of piercing the veil for corporate abuse was widely accepted in the first half of

29 Prest, at para 69: “...where a court is of the view (albeit that I think that it was mistaken in those cases) that there is no other method of achieving justice, the doctrine provides a valuable means of doing so." 
the 20 th century, ${ }^{30}$ but has been overcome since, ${ }^{31}$ so that today - with the notable exception of a Vermögensvermischung (= commingling of assets) ${ }^{32}-$ no case of true veil-piercing is recognised any more. ${ }^{33}$

Meanwhile, it remains to be seen whether the doctrine of piercing the veil has really been "analysed into oblivion" ${ }^{34}$ by Prest and whether the rule of last resort, despite its inherent uncertainties, will provide a sufficient barrier to veil-piercing claims. If so, the theoretical shortcomings of the new law may not weigh too heavily on practice. It seems that it is time to say goodbye, for the doctrine of piercing the veil is on its way to its own Brexit.

30 See e.g. BGHZ 20, 1, 4: "Beim absichtlichen Mißbrauch der juristischen Person kann es nicht schwerfallen, die durch das Rechtssubjekt verdeckte Wirklichkeit bloßzulegen”; BGHZ 31, 258; BGHZ 54, 222; for a theoretical foundation see Serick, Rechtsform und Realität juristischer Personen, 1955, p. 203 et seq.

31 The most powerful criticism was raised by Müller-Freienfels, AcP 156 (1957), 522 et seq.

32 BGHZ 125, 366; confirmed in a dictum in BGHZ 173, 246, at para. 27. Contrast the fierce rejection of commingling of assets as justification for piercing the veil in Prest, at para. 41 (per Lord Sumption).

33 Today, archetypical cases of corporate abuse are covered by the general law of torts, namely $\ 826 \mathrm{BGB}$, see BGHZ 173, 246 - Trihotel (Existenzvernichtungshaftung against asset shifting); BGHZ 176, 204 - Gamma (tort liability for gross underfunding); for an account, see Schall, Festschrift Eberhard Stilz, 2014, p. 537 et seq.

34 James Pearce-Smith, Can the corporate veil still be pierced, 2 Oct. 2014, available at http://www.stjohnschambers.co.uk/dashboard/wp-content/uploads/2014/10/Can-thecorporate-veil-still-be-pierced.pdf. 